\title{
Weight and Volume of Whole Thyroid Gland In Bangladeshi People: A Postmortem Study
}

\author{
Fakhrul Amin Mohammad Hasanul Banna ${ }^{1}$, Zakia Sultana ${ }^{2}$, Mansur Khalii ${ }^{3}$, Seheli Zannat \\ Sultana ${ }^{4}$, Sheikh Muhammad Abu Bakar ${ }^{5}$, Abdul Quddus ${ }^{6}$, Fashiur Rahman ${ }^{7}$
}

\begin{abstract}
Context: The thyroid is a brownish red, highly vascular earliest endocrine glandular structure appears in mammal. The size of thyroid gland varies considerably with age, sex, physiologic state, race and geographical location. It is larger and heavier in females than in males, and it hypertrophies during menstruation and pregnancy. So this study is to carry out the macroscopic architecture of thyroid gland of different age groups in Bangladeshi people to establish a normal standard.
\end{abstract}

Study design: Descriptive cross-sectional study.

Place and period of study: Department of Anatomy, Sylhet M. A. G. Osmani Medical College, Sylhet, from July 2006 to June 2007.

Materials: The study was carried out on 43 autopsied human thyroid glands aged 5 to 65 years. Thyroid glands were collected from unclaimed dead bodies autopsied in morgue of Sylhet M. A. G. Osmani Medical College, Sylhet.

Methods: The collected specimens were divided into age group $A$ (20 years and below), group B (21 to 50 years) and group $C$ (above 50 years). All specimens were examined morphologically by fine dissection method.

Result: The mean weight and volume of the thyroid gland was $13.27 \pm 5.82 \mathrm{gm}$ and $11.62 \pm 4.76 \mathrm{ml}$ respectively which are significant $(p<0.01)$.

Conclusion: From observation and results it reached conclusion that evidenced by weight and volume, the size and glandular structure gradually increase with age up to adolescence, remain stable in young and middle aged adult then slowly decline in old age. The present study will help to increase the information pool on the anatomy of thyroid gland of Bangladeshi people. To establish a normal standard for Bangladeshi people, further studies with large samples from different zones including goitre endemic zones of the country are suggested.

Keywords: weight, volume, thyroid gland, postmortem.

1. Assistant Professor of Anatomy, Ad-din Women's Medical College, Dhaka.

2. Professor and I lead of Anatomy, Sylhet MAG Osmani Medical College, Sylhet

3. Professor and Head of Anatomy, Chittagong Medical College, Chittagong

4. Associate Professor, Department of Anatomy, Mymensingh Medical College, Mymensingh

5. Assistant Professor of Anatomy, Ibrahim Medical College, Dhaka.

6. Associate Professor, Department of Anatomy, Jalalabad Ragib Rabeya Medical College, Sylhet

7. Assistant Professor, Department of Dermatology \& Venereology, Mymensingh Medical College, Mymensingh

Correspondence: Dr. Fakhrul Amin Mohammad Hasanul Banna
Introduction:

The thyroid is a brownish red, highly vascular earliest endocrine glandular structure appears in mammal. Weight of thyroid gland is about $25 \mathrm{gm}$. It is found that weight of thyroid gland is less in Jamaica, Japan and South Carolina than in Americans \& Europeans. This reduction is probably due to a generalized reduction in body size. It is evidence that severe cold stress is accompanied by increased thyroidal activity and hypometabolic state develops in tropical residents ${ }^{1}$.

The size of thyroid gland varies considerably with age, sex, physiologic state, race and geographical location. It is larger and heavier in females than in males. and it hypertrophies during menstruation and 
pregnancy ${ }^{2}$. Any abnormal enlargement of the thyroid gland is called goitre. Major enlargements may be associated with either excessive or deficient production of thyroid hormones ${ }^{3}$.

\section{Materials:}

This study was done on 43 (forty three) male human thyroid glands though fifty-four (54) specimen of both sexes studied. These entire samples were collected from unclaimed autopsied bodies in the morgue of the department of Forensic Medicine of Sylhet M.A.G. Osmani Medical College after requisite legal formalities. Samples were collected from medicolegal cases within twenty-four (24) hours after death before appearance of signs of putrefaction. The human thyroid gland with related structures was collected as enmass.

The collected samples were washed gently with tap water. Blood and blood clots were removed. Each sample was tagged with a piece of waxed cloth which bear an identification number along with the age and sex of the victim. Then the sample was fixed and preserved in $10 \%$ formol saline solution.

\section{Methods:}

Place and duration of study:

This study was carried out in the Department of Anatomy, Sylhet M.A.G. Osmani Medical College from July 2006 to June 2007. Age and sex of cadaver were collected from Department of Forensic Medicine, recorded in the register book against respective number of the sample.

\section{Grouping of the samples:}

Grouping of the samples was done according to age group A (20 years and below), group B (21 to 50 years) and group $C$ (above 50 years) ${ }^{4}$.

\section{Measurement of the weight of the whole thyroid gland:}

The thyroid gland was separated from other structures of the specimen. Excess water was soaked with a blotting paper and the gland was weighted on an analytic balance ${ }^{1}$.

\section{Measurement of the volume of the whole thyroid gland}

After taking the weight of the gland, the volume was measured by fluid displacement method. A jar was filled with water and the thyroid gland was gently placed in the fluid to allow gentle and complete immersion. Then the displaced fluid was collected in a measuring glass cylinder and volume of the fluid was determined ${ }^{4,5}$

\section{Results:}

Result of weight of the whole thyroid gland:

The results are expressed in Figs.-1, Tables-I. The mean weight of Group A was significantly lower than Group B $(p<0.01)$. The weight of thyroid glands

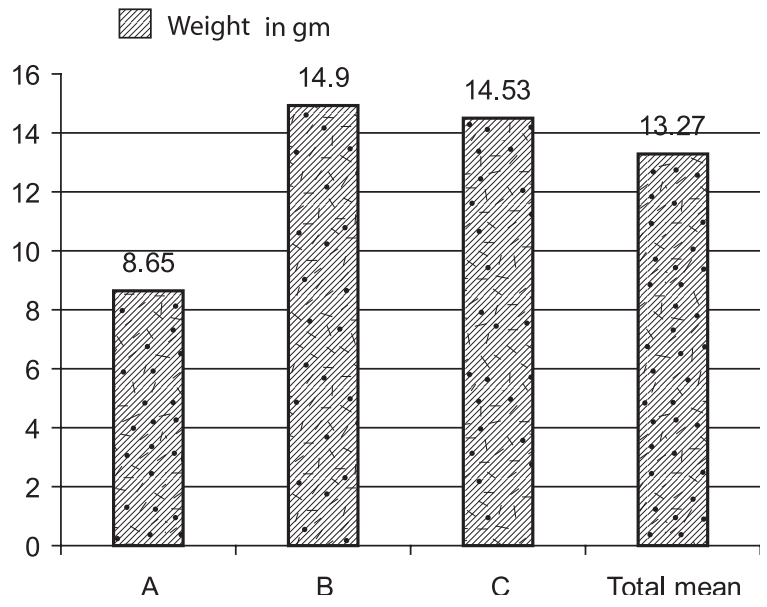

Fig.-1: Bar diagram-showing comparison of weight of whole thyroid gland between age groups.

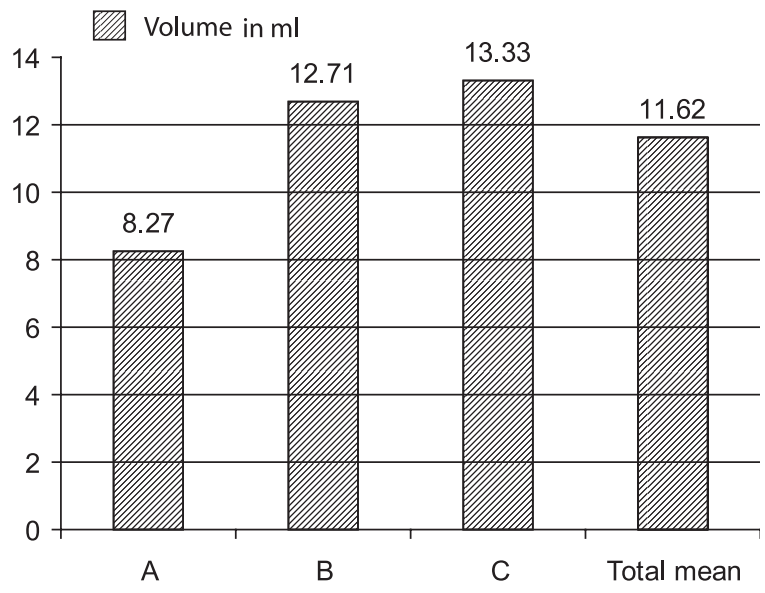

Fig.-2: Bar diagram-showing comparison of volume of whole thyroid gland between age group. 
shows positive correlation $(r=+0.426)$ with age, which is significant $(p<0.01)$.

Result of volume of the whole thyroid gland:

The results are expressed in Figs. 2, tables II. The mean volume of Group A was significantly lower than Group B $(p<0.05)$. The volume of thyroid glands shows positive correlation $(r=+0.421)$ with age, which is significant $(p<0.01)$.

Table - I

Weight of the thyroid gland in different age groups

\begin{tabular}{lccc}
\hline Group & $\begin{array}{c}\text { Number of } \\
\text { specimen }\end{array}$ & \multicolumn{2}{c}{ Weight in gm } \\
& Range & Mean \pm SD \\
\hline A & 11 & $2.32-21.30$ & $8.65 \pm 5.43$ \\
B & 29 & $6.45-28.80$ & $14.9 \pm 5.30$ \\
C & 03 & $11.1-18.30$ & $14.53 \pm 3.61$ \\
Total & 43 & $2.32-28.80$ & $13.27 \pm 5.82$ \\
\hline
\end{tabular}

Comparison between different age and sex groups (done by ' $\mathrm{t}$ ' test)

A vs $B-<0.01(S)$

$B$ vs $C->0.05$ (NS)

A vs $\mathrm{C}->0.05$ (NS)

Note: NS =Not significant, $\mathrm{S}=$ Significant

Table-II

Volume of the thyroid gland in different age groups

\begin{tabular}{lccc}
\hline Group & $\begin{array}{c}\text { Number of } \\
\text { specimen } \\
(\mathrm{n})\end{array}$ & \multicolumn{2}{c}{ Volume in $\mathrm{ml}$} \\
& Range & Mean \pm SD \\
\hline A & 11 & $2.5-19.0$ & $8.27 \pm 4.60$ \\
B & 29 & $7.0-20.5$ & $12.71 \pm 4.24$ \\
C & 03 & $8.5-20.0$ & $13.33 \pm 5.97$ \\
Total & 43 & $2.5-20.5$ & $11.62 \pm 4.76$ \\
\hline
\end{tabular}

Comparison between different age and sex groups (done by ' $\mathrm{t}$ ' test) A vs B $-<0.05$ (S)

$B$ vs $C->0.05$ (NS) A vs $C->0.05$ (NS)

Note: NS = Not significant, $\mathrm{S}=$ Significant

\section{Discussion:}

In textbooks the weight of the thyroid gland described usually $25 \mathrm{gm}$ by Standring et al., Sinnatamby and Decker which was slightly higher than that of present study ${ }^{6-8}$. Fawcett described that the weight of thyroid gland is about 25 to 40 gm which was also higher than that of present study ${ }^{9}$. According to Greenspan and Gardner the weight of thyroid gland is about 10 to $20 \mathrm{gm}^{10}$. Other authors like Greep and Weiss, Hoyes and Kerhsaw, Kelly et al. described that the weight of thyroid gland is about 15 to $20 \mathrm{gm}$ on an average in adult ${ }^{11-13}$. Other authors like DeGroot et al., Keele et $a$. and Kumar et al. also described that the weight of thyroid gland is between range 15 to $25 \mathrm{gm}^{14,15,16}$. Most of the authors did not mention the age of the population. If it is taken as the adult weight the value is similar to the present study. The value of this study was similar to the study done by Harjeet et al in northwest Indians and Enayetullah, Begum on thyroid glands of Bangladeshi people ${ }^{17,18,19}$. Mortensen et al. observed that the average weight of the normal thyroid glands depends almost entirely on the age of the patient and is not consistently affected by the sex or their usual geographic residence ${ }^{20}$.

Roberts studied on 78 cases (57 male and 21 female) aged 2 months - 98 years and found that during the first 20 years of life, the volume of thyroid gland rise in a linear fashion. With senescence the volume of the glands become reduced due to reduced mean size and volume of the thyroid follicle ${ }^{5}$. Brown et al. showed that thyroid volume increased with age during childhood and adolescence, remained fairly constant in younger adults and declined more slowly in older people 4 . The finding of present study was similar to this study. Enayetullah and Begum in their studies on Bangladeshi people and Harjeet et al. on northwest Indians also found the similar observation 17,18,19.

Hegedus et al. studied the volume of thyroid gland and its relationship to body weight, age and sex in normal subjects. They measured the volume of thyroid gland in vivo using an accurate ultrasonic scanning method on 271 normal healthy rcrson's (139 male and 132 female) aged 13 - 91 years. They found mean thyroid volume of $18.5 \pm 4.5 \mathrm{ml}$ and a significant difference in volume of thyroid gland between male $(19.6 \mathrm{t} 4.7 \mathrm{ml})$ and females $(17.5 \pm 4.2 \mathrm{ml})$. There was no significant difference in thyroid volume to body weight ratio between males and females ${ }^{21}$.

Hegedus et al. described that thyroid volume was significantly higher in the autum and winter than in the summer ${ }^{22}$. 


\section{References:}

1. Harland WA. Morphology of the thyroid gland in Jamaica. J Clin Endocrinol 1964; 24: 580-5.

2. Edwards LF, Gaughran GRL. Concise anatomy, 3rd ed. New York: McGraw-Hill; 1971. p. 509-12.

3. Mitchell GAG, Patterson EL. Basic Anatomy, 2nd ed. Edinburgh: E \& S Livingstone; 1967. p. 548-50.

4. Brown RA, AI-Moussa M, Beck JS. Histometry of normal thyroid in man. J Clin Pathol 1986; 39: 475-82.

5. Roberts PF. Variation in the morphometry of the normal human thyroid in growth and aging. J Pathol 1974; 112(3): 161-8.

6. Standring $\mathrm{S}$, Ellis $\mathrm{H}$, Healy $\mathrm{JC}$, Johnson $\mathrm{D}$, Williams. Gray's Anatomy: The anatomical basis of clinical practice, 39th ed. Edinburgh: Churchill Livingstone; 2005. p. 560-6.

7. Sinnatamby CS. Head and neck and spine. In: Last's anatomy: regional and applied, 10th ed. Edinburgh: Churchill Livingstone;1999. p. 324-36.

8. Decker GAG, Plessis DJD. Lee McGregor's Synopsis of Surgical Anatomy, 12th ed. Bombay: Varghese Publishing House; 1986. p. 198-207.

9. Fawcett DW, Raviola E. Bloom and Fawcett: A text book of histology, 12th ed. New York: Chapman \& Hall; 1994. p. 490-502.

10. Greenspan FS, Gardner DG. Basic \& Clinical Endocrinology, 6th ed. New York: McGrawHill; 2001. p. 201-31.

11. Grecp RO, Weiss L. The thyroid gland. In: Histology, 3rd ed. New York: McGraw-Hill; 1973. p.925-34.

12. Hoyes AD, Kershaw DR. Anatomy and development of the thyroid gland. Ear Nose Throat J 1985; 64: 318-33.
13. Kelly DE, Wood RL, Enders AC. Bailey's textbook of microscopic anatomy, 18th ed. Baltimore: Williams \& Wilkins;1984. p. 794-804.

14. DeGroot LJ, Jameson IL. ed. Endocrinology. 4th ed. Philadelphia: WB Saunders; 2001. p. 1268-77.

15. Keele CA. Neil E, Joels N. Samson Wright's applied physiology, 13th ed. Oxford: Oxford University Press: 2005. p. 537-53.

16. Kumar V, Abbas AK, Fausto N. Robbins SL. Robbins and Cotran Pathologic Basis of Disease, 7th ed. Philadelphia: WB Saunders; 2004. p. 1164-89.

17. Harjeet A, Sahni D, Jit I, Aggarwal AK. Shape, measurments and weight of the thyroid gland in northwest Indians. Surg Radiol Anat 2004: 26(2): 91-95.

18. Enayetullah M. Gross and histomorphological study of thyroid and parathyroid glands in Bangladeshi people (thesis). University of Dhaka; 1996.

19. Begum M. Gross and histomorphological study of human postmortem thyroid gland in Bangladeshi people (thesis). University of Dhaka; 2004.

20. Mortensen JD, Woolner LB, Bennett WA. Gross and microscopic findings in clinically normal thyroid glands. J Clin Endocrinol Metab 1955; 15: 1270-80.

21. Hegedus L, Perrild H, Poulsen LR, Andersen JR. Holm B, Schnohr P, et al. The determination of thyroid volume by ultrasound and its relationship to body weight, age and sex in normal subjects. J Clin Endoerinol Metab 1983: 56(2): 260-3.

22. Hegedus L, Rasmussen N, Knudsen N. Seasonal van variation in thyroid size in healthy males. Horm Metabol Res 1987; 19(8): 391-2. 